\title{
PERAN TINGKAT INTELEGENSI DAN MOTIVASI BELAJAR DALAM MENINGKATKAN PRESTASI BELAJAR EKONOMI di SMA NEGERI GUGUS 01 KABUPATEN TANGERANG
}

\author{
${ }^{1}$ Heru Sriyono dan ${ }^{2}$ Wahyudin \\ ${ }^{1}$ Dosen Magister Pendidikan IPS Universitas Indraprasta PGRI \\ ${ }^{2}$ Mahasiswa Magister Pendidikan IPS Universitas Indraprasta PGRI
}

\begin{abstract}
Abstrak
Tujuan penelitian ini adalah untuk mengetahui pengaruh Tingkat intelegensi dan Motivasi belajar terhadap Prestasi belajar Ekonomi. Metode penelitian yang digunakan adalah metode survey. Sampel diambil sebanyak 60 siswa dengan teknik acak sederhana. Pengumpulan data dilakukan dengan penyebaran angket langsung kepada sampel. Analisis data menggunakan statistika deskriptif seperti mencari mean, median, standar deviasi dan statistika inferensial yaitu untuk mencari koefisien korelasi sederhana dan ganda yang dilanjutkan dengan uji signifikansi koefisien korelasi dengan uji t. Hasil penelitian menunjukkan: 1) Terdapat pengaruh yang signifikan Tingkat intelegensi dan Motivasi belajar terhadap Prestasi belajar Ekonomi siswa SMA Negeri di gugus 01 Kabupaten Tangerang. Hal tersebut dibuktikan dengan nilai sig $0,000<0,005$ dan F hitung 13,037 yang berarti bahwa terdapat kontribusi Intelegensi dan Motivasi belajar terhadap Prestasi belajar Ekonomi sebesar 31,4\%.2) Terdapat pengaruh yang signifikan Tingkat intelegensi terhadap Prestasi belajar Ekonomi siswa SMA Negeri di Gugus 01 Kabupaten Tangerang. Hal ini dibuktikan dengan nilai sig $0,010<0.05$ dan thitung $=2,674$ yang menunjukkan bahwa terdapat kontribusi Intelegensi terhadap prestasi belajar ekonomi sebesar $15,81 \%$. 3) Terdapat pengaruh yang signifikan motivasi belajar terhadap prestasi belajar ekonomi siswa SMA Negeri di Gugus 01 Kabupaten Tangerng dibuktikan dengan nilai sig 0,011 $<0,05$ dan t hitung $=2,644$ yang menunjukkan bahwa kontribusi motivasi belajar terhadap prestasi belajar Ekonomi sebesar 15,55\%.
\end{abstract}

Kata kunci: Tingkat Intelegensi, Motivasi belajar, Prestasi belajar Ekonomi

\section{PENDAHULUAN}

Inteligensi (IQ) tinggi akan dapat memperoleh prestasi belajar yang tinggi pula, karena Inteligensi (IQ) merupakan bekal potensial yang akan memudahkan dalam belajar dan pada gilirannya akan menghasilkan prestasi belajar yang optimal.

Walaupun demikian, dalam proses belajar-mengajar di sekolah sering ditemukan siswa yang tidak dapat meraih prestasi belajar yang setara dengan kemampuan Inteligensinya. Ada siswa yang mempunyai kemampuan Inteligensi (IQ) tinggi tetapi memperoleh prestasi belajar yang relatif rendah, bahkan ada siswa yang walaupun kemampuan Inteligensinya relatif rendah dapat meraih prestasi belajar yang relatif tinggi.

Faktor-faktor yang mempengaruhi prestasi belajar banyak jenisnya, tetapi dapat digolongkan menjadi 2 golongan saja yaitu: (a) faktor intern, meliputi faktor fisiologis dan fsikologis. Faktor fisiologis seperti keadaan jasmaani dan panca indra. Faktor Psykologis seperti intelegensi, minat dan motivasi. (b) Faktor ektern, meliputi faktos sosian dan non sosial. Faktor soasial, seperti lingkungan keluarga, sekolah dan 
masyarakat. Faktor non sosial, seperti lingkugan alam dan fisik yakni keadaan rumah, ruang belajar, fasilitas belajar, nuku sumber dan lain sebagainya (Mulyasa, 2004: 191193).

Faktor lain yang juga menentukan prestasi belajar adalah lingkungan belajar. Secara umum pengertian lingkungan belajar tersebut sangat luas, dapat meliputi: sosiologi, psikologi dan sosiokultur, ketiga aspek tersebut keberadaannya saling mendukung lingkungan belajar yang kondusif. Yaitu lingkungan yang mendukung terciptanya kegiatan belajar mengajar yang nyaman, tenang dan tentram. Oleh sebab itu, Intelegensi dan Motivasi Belajar harus dapat menciptakan suasana itu apabila mengharapkan prestasi belajar yang baik karena Intelegensi dan Motivasi Belajar merupakan lembaga pertama yang memberikan proses pendidikan dan sangat besar pengaruhnya terhadap keberhasilan anak atau peserta didik.

Anak atau siswa dalam perkembangannya membutuhkan perhatian dari orang tua, guru maupun teman-temannya, dengan perhatian tersebut maka akan tercipta keharmonisan hubungan diantara mereka, yang dimungkinkan dapat membantu proses pelaksanaan kegiatan belajar mengajar, sehingga dapat koreksi akan kekurangan dan kelemahan diantara siswa, orang tua dan guru.

Usaha yang dilakukan oleh berbagai pihak baik keluarga, masyarakat maupun pemerintah dengan adanya Wajib Belajar 12 Tahun dalam meningkatkan belajar siswa termasuk di dalamnuya orang tua dalam menggerakkan, mendorong dan memberikan perhatian terhadap anaknya akan dapat membantu siswa dalam meningkatkan prestasi belajar.

Di dalam meningkatkan prestasi belajar banyak dipengaruhi oleh Intelegensi dan Motivasi Belajar yang meliputi ekonomi keluarga, tingkat pendidikan orang tua, perhatian seluruh keluarga, penggunaan waktu dalam membantu orang tua, lamanya waktu belajar di rumah, ada tidaknya tempat belajar, mengikuti acara TV dan intensitas pertemuan dengan orang tuanya. Di sini dibutuhkan sekali peran serta orang tua dalam mengatur dan menetapkan frekuensi belajar siswa di rumah dalam mengulang pelajaran yang didapatkan di sekolah serta mengajarkan latihan-latihan soal. Jika siswa dengan keluarganya meluangkan waktunya di rumah cukup untuk proses belajar-mengajar niscaya pada saat tes anak/siswa tersebut akan mudah menjawab soal, karena telah sering berlatih niscaya akan mendapatkan prestasi belajar yang baik. Sebagai orang tua yang 
perhatian dalam keluarga harus menanamkan disiplin pada anaknya, kapan harus belajar, kapan waktunya nonton TV dan waktunya dapat bermain-main serta dapat membantu orang tuanya. Sebab pada saat sekarang ini jam belajar siswa di rumah cenderung berkurang karena hadirnya berbagai stasiun televisi swasta yang menawarkan aneka tontonan yang lebih banyak bersifat menghibur dari pada mendidik.

Keluarga yang harmonis sadar dan mengerti arti pendidikan akan memberi kesempatan, bimbingan dan dorongan yang positif terhadap perkembangan proses pendidikan. Kepedulian orang tua terhadap pendidikan juga membawa pengaruh terhadap anak, apabila orang tua kurang antusias terhadap pendidikan, anak jadi kurang termotivasi dalam belajar.

Karena jika perhatian orang tua terhadap anaknya atau siswa buruk maka tidak menutup kemungkinan bahwa prestasi belajar siswa tersebut akan buruk juga. Sebab prestasi belajar siswa juga dipengaruhi oleh kondisi fisik (kesehatan), kecerdasan, bakat, minat baca, frekuensi belajar dan keteraturan dalam belajar, situasi sekolah dan di rumah baik, dimana semua faktor tersebut akan menjadi faktor yang membawa dampak positif bagi peningkatan prestasi belajar siswa jika siswa/anak tersebut mendapatkan dorongan dan perhatian yang cukup dari orang tuanya. Kecenderungan prestasi belajar siswa/anak turun dapat juga diakibatkan karena pengelolaan sarana pendidikan di sekolah masih buruk, latar belakang pendidikan orang tua yang rendah, kesibukan orang tua, kurangnya intensitas evaluasi yang diberikan pihak sekolah kepada siswa dari perhatian yang diberikan orang tua.

\section{TINJAUAN PUSTAKA}

\section{Pengertian Belajar}

Banyak ahli pendidikan mengungkapkan pengertian belajar dengan sudut pandang mereka masing-masing. Penulis akan mengemukakan kembali beberapa pengertian belajar dari sudut pandang yang hampir sama diantaranya:

Menurut James Whittaker (Jaali, 2008:38) mengemukakan bahwa: "belajar adalah proses dimana tingkah laku ditimbulkan atau diubah melalui latihan atau pengalaman”.

Dari beberapa pendapat diatas ditunjukkan bahwa belajar adalah perubahan tingkah laku atau kecakapan manusia yang relatif permanen sebagai akibat interaksi dengan lingkungan atau pengalaman. 


\section{Pengertian Prestasi Belajar}

Prestasi belajar, yang dalam konteks proses belajar mengajar di sekolah seringkali dibahas dalam sub judul kinerja akademik (academic performance), merupakan prestasi belajar seorang siswa. Menurut Jaali (2008:37): "prestasi belajar (achievement) merupakan kinerja akademik prestasi belajar seorang siswa, yang dapat diketahui melalui tes prestasi belajar".

Pembelajaran adalah "proses pengajaran berpusat pada tujuan yang dalam banyak hal direncanakan sebelumnya. Sehingga pembelajaran merupakan sarana untuk memungkinkan terjadinya proses belajar dalam arti perubahan tingkah laku individu melalui proses mengalami

Menurut Jaali (2008:107) prestasi belajar merupakan penilaian terhadap usaha yang berarti menetapkan apakah usaha itu berhasil atau tidak.

Oemar Hamalik (2006) mengemukakan bahwa: "prestasi belajar adalah interaksi dari beberapa faktor yang saling mempengaruhi baik dari dalam diri individu maupun dari luar individu yang bersangkutan".

Prestasi belajar yang diterapkan adalah siswa memiliki pengetahuan, ketrampilan dan kecakapan berfikir yang baik.

Kinerja (performance) ini dapat mengindikasikan seberapa baik seorang siswa menguasai konten kurikulum sekolah. Karena itu, sepantasnyalah prestasi belajar Matematika dan Bahasa Indonesia para siswa Sekolah Dasar memuaskan, karena dengan demikian berarti penguasaan para siswa SD tersebut atas Matematika dan Bahasa Indonesia adalah memuaskan.

Dikaitkan dengan teori feuerstein, mediated learning experience (MLE), khususnya yang diberlakukan melalui Instrumental Enrichment (IE), merupakan salah satu metode yang memungkinkan seseorang berpikir fleksibel, bahkan dapat meningkatkan kemampuan berpikir dan Intelligence Quotient (IQ) seseorang, atau dengan kata lain, MLE melalui IE dapat meningkatkan kemampuan seseorang dalam bernalar.

Dari beberapa pendapat tersebut dapat disimpulkan bahwa prestasi atau prestasi belajar adalah nilai yang dapat dicapai oleh seseorang dengan kemampuan maksimal setelah seseorang tersebut mengikuti kegiatan pembelajaran. 


\section{Faktor-faktor yang mempengaruhi prestasi belajar}

Ada dua faktor yang mampengaruhi prestasi belajar, yaitu Faktor intern dan ekstern.

1. Faktor Intern, terdiri dari: a) faktor jasmaniah antara lain : faktor kesehatan dan cacat tubuh. b) faktor psikologis yaitu : intelegensi, perhatian, minat, bakat, motivasi, kematangan dan kesiapan. c) faktor kelelahan, faktor kelehan sangat mempengaruhi hasil belajar agar siswa dapat belajar dengan baik haruslah menghindari jangan sampai terjadi kelelahan dalam belajarnya, sehingga perlu diusahakan kondisi yang bebas dari kelelahan.

2. Faktor ekstern, terdiri dari : a) faktor keluarga, seperti cara orang tua mendidik, relasi antar anggota, suasana rumah, keadaan ekonomi keluarga, pengertian orang tua dan latar belakang kebudayaan.. b) faktor sekolah, seperti metode mengajar, kurikulum, relasi guru dengan siswa, relasi siswa dengan siswa, disiplin sekolah, alat pelajaran, waktu sekolah, standar pengajaran di atas ukuran, keadaan gedung, metode belajar dan tugas rumah. c) faktor masyarakat, seperti kegiatan siswa dalam masyarakat, teman gaul dan bentuk kegiatan dalam masyarakat. (Slameto, 2010:54).

Dalam membahas faktor-faktor yang mempengaruhi prestasi belajar ini, perlu dikaji adanya dua pendapat yang bertentangan. Pertama, menrut Coleman dkk. Yang dikutip, Winkel, (1996:128) mengungkapkan:

"hasil penelitiannya, bahwa faktor-faktor non sekolah lebih berperan terhadap prestasi siswa dibandingkan dengan faktor-faktor sekolah. Faktor-faktor non sekolah termasuk di dalamnya latar belakang keluarga, kelas sosial, lokasi sekolah di Utara atau di Selatan, setting sekolah di daerah rural atau urban, dan pengaruh sebaya dan tradisi. Sedangkan faktor-faktor sekolah adalah jumlah uang yang digunakan dalam pendidikan, bahkan proses pengajaran itu sendiri“.

Pandangan yang bertentangan dengan pandangan Coleman tersebut adalah pandangan dari Davis dan Thomas. Meraka menganggap pandangan Coleman sangat pesimistis dan kurang tepat. Menurut Davis dan Thomas, berdasarkan penelitianpenelitian (Edmonds; Rutter, Mugham, Mortimore, Ouston \& Smith; Weber) yang dikutip kembali Winkel, (1996:156) : "sekolah-sekolah yang efektif, yang mampu mengajarkan keterampilan-keterampilan dasar secara lebih baik dari sekolah-sekolah lainnya benar-benar ada". Davis dan Thomas juga mengungkapkan bahwa: "faktorfaktor keluarga dan masyarakat, khususnya status sosial ekonomi memang 
mempengaruhi prestasi. Namun terdapat bukti bahwa struktur sekolah, iklim sekolah, kepemimpinan dan praktek-praktek pengajaran mempengaruhi prestasi dan sikap terhadap sekolah".

Menurut Winkel, W.S. (1996:160): “banyak faktor yang mempengaruhi prestasi belajar, seperti lingkungan, pengajaran dan manajemen berelasi satu sama lain. Artinya, kelemahan pada salah satu akan terkait dengan kekurangan di faktor yang lain”.

\section{Pengukuran Prestasi Belajar}

Prestasi belajar seorang siswa dapat diketahui melalui tes-tes prestasi belajar yang umumnya disusun oleh pihak sekolah (guru), dan diujikan kepada para siswa setelah sesi tertentu dari suatu rangkaian proses belajar.

Menurut Jaali (2008:31) : "kinerja siswa biasanya diukur dengan kombinasi beberapa tes dan tugas yang diberikan oleh guru".

Prestasi belajar umumnya diukur melalui tes. Tes prestasi belajar ini merupakan evaluasi dari status individu dalam menyelesaikan suatu pelatihan".

Pengukuran kinerja akademik, yang seringkali disebut evaluasi prestasi belajar, Menurut Jaali (2008:38):

"Prestasi belajar seringkali digunakan sebagai dasar utama untuk kenaikan, dan digunakan untuk mencap anak dapat atau tidak dapat, sukses atau gagal, meskipun sebenarnya berbagai faktor dapat berpengaruh penilaian atau evaluasi prestasi belajar, mempengaruhi validitas sebagai pengukuran independen terhadap penguasaan siswa pada materi pelajaran“".

Sesungguhnya, peran tes prestasi dalam proses pendidikan sudah diakui sejak lama. Salah satu antaranya adalah sebagai suatu alat untuk menentukan tingkat pendidikan siswa. Terdapat peran lain dari tes prestasi belajar, misalnya untuk memberi gambaran akan petingnya program remedial bagi siswa, untuk memberikan umpan balik baik bagi guru maupun siswa, dan untuk mengetahui kemajuan belajar siswa.

Tes prestasi belajar dapat berbentuk lisan, tertulis atau perbuatan. Untuk tes tertulis, paling tidak terdapat empat tipe yaitu: Betul-Salah, Menjodohkan, dan Pilihan Ganda yang dapat digolongkan ke dalam tes obyektif, dan tes uraian atau tes karangan. Penyusunan tes prestasi belajar harus memenuhi kaidah-kaidah yang telah ditentukan. (Winkel, 1996:98). 
Dari beberapa pendapat dan kondisi tersebut dapat disimpulkan bahwa pengukuran prestasi atau prestasi belajar adalah suatu kegiatan untuk memperoleh data tentang hasil kinerja peserta belajar selam dan setelah mengikuti kegiatan pembelajaran.

\section{Pengertian Prestasi Belajar Ekonomi}

Kemampuan seorang siswa di bidang studi IPS akan tergambar melalui penguasaannya terhadap materi pelajaran sosiologi, geografi, ekonomi dan sejarah. Penguasaan materi tersebut dapat tergambar dalam prestasi belajar seseorang siswa. Prestasi belajar atau achievement merupakan salah satu Prestasi belajar yang diukur sebagai salah satu tujuan pengajaran. Mata pelajaran Ekonomi merupakan salah satu mata pelajaran di sekolah yang menekankan pada pembelajaran tentang kehidupan manusia dan lingkungan sosial masyarakat di sekitarnya terutama yang berkaitan dengan usaha manusia dalam memenuhi hajat hidupnya. Belajar ilmu ekonomi sama artinya dengan pembelajaran tentang sosial masyarakat. Ekonomi memiliki objek pembelajaran yang terkait dengan manusia dan semua peristiwa yang terjadi dalam lingkungan sosial masyarakat. Oleh karena itu, belajar ilmu ekonomi pun perlu diukur tingkat keberhasilannya melalui prestasi belajar yang diperoleh siswa. Prestasi belajar ilmu ekonomi mencupakan bagian akhir diri proses pembelajaran ilmu ekonomi yang dilakukan di sekolah. Dengan prestasi belajar ilmu ekonomi, siswa dapat mengetahui kemampuan dan pemahaman yang terkait dengan materi pembelajaran.

Prestasi belajar ilmu ekonomi pada dasarnya dapat terlihat melalui perubahan tingkah laku siswa dalam memandang dan memahami ilmu ekonomi. Oleh karena itu, Prestasi belajar ekonomi harus dapat menjadi indikator untuk mengukur kemampuan dan penguasaan siswa terhadap berbagai materi yang dipelajari dalam ilmu ekonomi.

Pembelajaran ilmu ekonomi menekankan pada kemampuan siswa dalam mengamati, menganalisis, dan menerapkan ilmu yang berkaitan dengan manusia dengan lingkungan sosial masyarakat sekitarnya. Pembelajaran ilmu ekonomi tidak hanya terbatas pada penguasaan terhadap pengetahuan ilmu ekonomi semata, tetapi juga harus diikuti dengan upaya untuk menerapkannya dalam mengamati manusia dengan segala proses sosial dalam pemenuhian hajat hidupnya yang menyertainya. prestasi belajar ilmu ekonomi juga tencermin melalui pengetahuan dan keterampilan siswa dalam memecahkan setiap masalah yang terkait dengan pelajaran ekonomi, serta tercermin 
melalui sikap siswa dalam kehidupan sehari-hari yang terkait dengan wawasannya tentang ilmu ekonomi.

Dari uraian di atas dapat disimpulkan bahwa prestasi belajar ekonomi adalah tingkat pencapaian kemampuan pengetahuan siswa pada materi ilmu ekonomi, serta pencapaian ketrampilan dan sikap yang terkait dengan wawasan tentang ilmu ekonomi.

\section{Pengertian inteligensi}

Inteligensi atau kemampuan menerima dan memecahkan masalah adalah faktor yang menggerakkan siswa sehingga ia berhasil atau gagal dalam menghadapi lingkungan belajarnya. Intelegensi sebagai sumber potensi belajar memiliki banyak definisi. Menurut Garrt, "Intelligence, includes at least the ablities demanded in the solution of problems which require the comprehension and use of symbols". Dalam definisi Garrt ditekankan bahwa,"inteligensi setidak-tidaknya mencakup kemampuan yang diperlukan untuk pemecahan masalah-masalah yang memerlukan pengertian serta menggunakan simbolsimbol". Rumusan definisi yang berbeda namun pengertiannya sama dengan yang dikemukakan oleh Garrt dan Bischof dikemukakan oleh Heidenrich yaitu "Intelligenxce refers to the ability to learn and to utilize what has been learned in adjuting to unfamiliar situations, or in the solving of problems"

Dari pendapat ketiga ahli di atas dapat disimpulkan bahwa inteligensi adalah kemampuan memecahkan masalah, baik masalah pribadi, akademik, keluarga, sosial, maupun ekonomi.

Inteligensi sebagai sumber potensi belajar memiliki berbagai faktor yang dapat berpengaruh pada tinggi rendahnya kemampuan yang dapat diterapkan oleh peserta didik dalam proses pembelajaran.

Dari pengertian di atas, dapat disimpulkan bahwa inteligensi adalah kemampuan atau kekuatan yang dimiliki seseorang untuk menyelesaikan atau memecahkan berbagai masalah yang dihadapinya. Oleh karena itu, inteligensi merupakan komponen keberhasilan dalam proses belajar siswa di sekolah.

\section{Faktor-Faktor yang mempengaruhi Inteligensi}

Dalam lingkungan pendidikan, salah satu tugas serta kewajiban pendidik adalah mengembangkan kemampuan intelektual siswa agar dapat berfungsi se-cara optimal. 
Perkembangan kemampuan inteligensi dipengaruhi oleh banyak faktor di antaranya sebagai berikut:

\section{Faktor keturunan.}

Pengaruh faktor keturunan bagi inteligensi sudah dibuktikan melalui berbagai penelitian yang mengkorelasikan IQ dengan berbagai tingkat hubungan genetik.

\section{Faktor lingkungan.}

Kualitas lingkungan yang kaya, merangsang dan menunjang dapat meningkatkan inteligensi anak. Pengaruh lingkungan ini mencakup nutrisi, kesehatan, kualitas stimulasi, iklim emosional dalam keluarga, dan tipe umpan balik yang diperoleh melalui interaksi anak dengan lingkungan itu. Di antara dua anak yang mempunyai gen sama, anak yang lebih baik nutrisi sebelum dan sesudah kelahirannya, yang lingkungan rumahnya lebih banyak memberikan stimulasi intelektual dan lebih aman secara emosional, dan yang mendapat ganjaran yang lebih tepat untuk prestasi akademisnya, akan memperoleh skor IQ yang lebih tinggi.

\section{Alat ukur Inteligensi}

Tes inteligensi adalah tes psikologis yang mengukur inteligensi seseorang, di mana tes itu merupakan salah satu alat bantu dalam pemeriksaan psikologis yang banyak digunakan oleh seorang psikolog untuk dapat memperoleh gambaran secara cepat, tepat, dan obyektif mengenai gambaran inteligensi seseorang.

Sehubungan dengan apa yang diukur oleh tes inteligensi ada beberapa macam tes inteligensi, yaitu:

1. Tes inteligensi umum yang bertujuan untuk memberikan gambaran yang umum mengenai taraf inteligensi umum dari seseorang.

2. Tes inteligensi khusus yang hanya memberikan keterangan tentang satu segi atau faktor yang spesifik dari inteligensi seseorang.

3. Tes inteligensi differensial yang memberikan gambaran mengenai kemampuan seseorang didalam berbagai segi atau faktor inteligensi yang memungkinkan didapatkannya profil atau gambaran segi-segi kekuatan dan kelemahan dari berfungsinya inteligensi seseorang.

Tes inteligensi yang sering digunakan di sekolah di antaranya:

1. Tes inteligensi dari Wechsler yang mengukur taraf inteligensi umum: 
a. khusus untuk anak yang berusia 4 tahun sampai 6 tahun digunakan W.P.P.S.I. (Wechsler Preschool and Primary Scale of Intelligence).

b. untuk anak yang berusia 6 tahun sampai 16 tahun digunakan W.1.S.C (Wechsler Intelligence Scale for Children).

c. untuk orang dewasa digunakan W.B. (Wechsler-Bellevue), dan W.A.I.S. (Wechsler Adult Intelligence Scale).

Tes Inteligensi Wechsler adalah tes individual, yang diberikan secara lisan dan dijawab secara lisan pula, serta dasar pengukurannya adalah deviation I.Q. dengan nilai ratarata $=100$ dan besar penyimpangan $=15$.

2. Tes CFIT (Culture Fair Intelligence Test) dari Cattell.

Tes ini dibuat oleh Raymond B.Cattel dan A. Karen S. Cattel, serta se-jumlah staf penelitian dari 'Institute of Personality and Ability Testing' di uni-versitas Illinois, Champaign, Amerika Serikat pada tahun 1949. Tes ini di-maksudkan untuk mengukur 'kemampuan umum' atau 'G' faktor. Menurut teori inteligensi yang dikemukakan oleh Cattel, CFIT adalah untuk mengukur fluid ability seseorang. Fluid ability adalah kemampuan kognitif seseorang bersifat herediter. Kemampuan kognitif yang 'fluid' ini, di dalam perkembangan individu selanjutnya mempengaruhi kemampuan kognitif lainnya yang disebut sebagai cristalized ability. Cristalized ability seseorang merupakan kemampuan kognitif yang diperoleh dalam interaksi dengan lingkungan di sekitarnya. Sampai seberapa jauh kemampuan kognitif seseorang adalah tergantung pada seberapa jauh keadaan fluid ability-nya dan bagaimana perkembangan cristalized ability-nya. Keuntungan dari pemakaian CFIT adalah:

a. Merupakan alat ukur yang dapat dipercaya untuk mengetahui kemampuan umum seseorang dalam waktu yang relatif singkat.

b. Dapat dipergunakan secara klasikal atau dalam kelompok 20 sampai 30 atau lebih di dalam kelas yang dipimpin oleh seorang psikolog.

CFIT mengalami beberapa kali revisi sejak disusunnya pertama kali pada tahun 1920an. Ada tiga skala seri CFIT yaitu skala 1 yang dirancang untuk digunakan anak pada usia 4 sampai 8 tahun, skala 2 dan skala 3 dipakai bagi anak usia 8 tahun dan anak yang lebih tua maupun orang dewasa. Pada skala 2 dan skala 3 diterbitkan dua bentuk yaitu bentuk A dan bentuk B. Penelitian yang dilakukan ini menggunakan CFIT 3A. Pada masing-masing skala 2 dan skala 3 ada empat subtes. 
Waktu untuk mengerjakan masing-masing subtess secara berurutan ialah 5 menit, 4 menit, 3 menit dan $2 \frac{1}{2}$ menit. Dasar pengukuran adalah deviation IQ, dengan nilai rata-rata $=100$, dan besar penyimpangan $=16$. Standardised Progressive Matrixes (SPM) dari Raven.

\section{Pengertian Motivasi belajar}

Pengertian motivasi belajar tidak dapat dipisahkan dari pengertian motivasi secara umum. Penelitian mengenai motivasi hampir selalu sinonim dengan penelitian tentang motivasi belajar.

Menurut Mc Donald yang dikutip Hamalik (2006:106), "Motivasi adalah suatu perubahan energi dalam diri (pribadi) seseorang yang ditandai dengan timbulnya perasaan dan reaksi untuk mencapai tujuan”.

Djaali (2008:109) berpendapat bahwa, "Motivasi belajar dapat diartikan sebagai dorongan untuk mengerjakan tugas dengan sebaik-baiknya dengan mengacu kepada standar keunggulan”. Untuk itu motivasi perlu dimiliki oleh setiap siswa. Siswa yang motivasi belajarnya tinggi; memiliki inisiatif untuk melakukan kegiatan berprestasi, bekerja dengan intensitas tinggi, sabar dalam menghadapi kegagalan dan memilih tugas yang taraf kesulitannya sedang. Siswa yang mengandalkan usaha dan kemampuan untuk mencapai tujuan maka dia akan bangga dengan keberhasilannya. Rasa penghargaan yang tinggi terhadap diri sendiri ini meningkatkan keinginan mereka berinisiatif pada langkahlangkah berprestasi berikutnya, dan cenderung ingin melajutkan hal yang berharga ini. Sedangkan siswa yang memiliki motivasi belajarnya rendah karena mengandalkan faktor eksternal daripada internal maka harga diri mereka tidak tinggi dan tidak memiliki inisiatif untuk berprestasi.

Siswa dengan motivasi belajar tinggi dapat mengatasi kemungkinan lebih berhasil pada tugas berikutnya dengan merencanakan usaha yang lebih keras. Sedangkan siswa yang motivasi belajarnya rendah karena menganggap sukses berasal dari keberuntungan dan gagal karena ketidakmampuan, maka mereka hanya berpandangan bahwa kegagalan demi kegagalan yang akan diperolehnya pada tugas berikutnya. Hal ini mengakibatkan usaha mereka untuk berprestasi semakin menurun.

Menurut pendapat Jhonson dan switzgebel dapat disimpulkan bahwa siswa yang memiliki motivasi belajar tinggi memiliki karakteristik sebagai berikut: 
1. Menyukai situasi atau tugas yang menuntut kemampuan pribadi atas hasil-hasilnya dan bukan atas dasar untung-untungan, nasib, ayau kebetulan.

2. Memilih tujuan yang realistis tetapi menantang dari tujuan yang terlalu mudah dicapai atau terlalu besar resikonya.

3. Mencari situasi atau pekerjaan di mana ia memperoleh umpan balik dengan segera dan nyata untuk menentukan baik atau tidaknya hasil pekerjaannya.

4. Senang bekerja sendiri dan bersaing untuk mengungguli orang lain.

5. Mampu menangguhkan keinginannya demi masa depan yang baik.

6. Tidak tergugah untuk sekedar mendapatkan uang, ia akan mencari apabila hal-hal tersebut merupakan lambang prestasi, suatu ukuran keberhasilan” (Djaali, 2008: 110)

Berdasarkan pendapat-pendapat yang telah dikemukakan di atas, dapat diartikan bahwa motivasi belajar yang dikemukakan dalam penelitian ini adalah usaha meningkatkan atau mempertahankan setinggi mungkin kecakapan yang dimiliki untuk mencapai tujuan.

\section{Teori Motivasi}

Pada tahun 1990, topik-topik motivasi berkisar pada kognisi (misalnya atribusi kausal), perbedaan individual dalam motivasi (misalnya kebutuhan berprestasi), dan pengaruh lingkungan terhadap motivasi (misalnya konteks kompetitif versus kooperatif).

Sampai saat ini, teori atribusi dan aplikasinya pada prestasi mendapat banyak perhatian, dan cenderung menjadi teori motivasi kontemporer yang dominan.

Teori-teori motivasi dapat tergambarkan melalui konstruk-konstruk yang membangun teori tersebut. Terdapat berbagai pendapat mengenai konstruk-konstruk yang berkaitan dengan motivasi. Para ahli ini menganggap keyakinan dan perilaku merupakan trait. sedangkan sebagian ahli yang lain memusatkan perhatian kepada konteks-konteks suatu saat. Sebagian terbesar peneliti mengenali bahwa baik disposisi individu, maupun lingkungan individu itu pada suatu saat tertentu merupakan hal yang penting.

"Kelompok pertama adalah konstruk yang berkaitan dengan persepsi diri mengenai kemampuan (ability selfperception), seperti self-worth, self-effcacy, helplessness beliefs, explanatory style, helpless versus mastery-oriented children. Sedangkan yang kelompok kedua termasuk dalam konstruk-konstruk yang berkaitan dengan tujuan prestasi (achievement goals), meliputi konstruk-konstruk task involvement versus ego 
involvement, insentif intrinsik versus ekstrinsik, struktur tujuan kooperatif, dan individualistik".

Berkaitan dengan kelompok konstruk yang kedua, salah satu penemuan adalah bahwa persepsi siswa mengenai implikasi upaya mereka bervariasi, dan variasi ini merupakan fungsi dari tujuan mereka. Siswa yang bertujuan menguasai materi (mastery goals), melakukan upaya yang lebih besar. Upaya ini berkaitan dengan perasaan kompeten yang lebih besar.

Ditinjau dari perspektifnya, teori motivasi dapat dipandang dari perspektif behavioral, humanistyc dan kognitif.

Dikaitkan dengan dasar teori Feuerstein yang menitikberatkan pada pentingnya interaksi sosial dalam meningkatkan kemampuan kognitif anak, maka teori motivasi yang paling sesuai digunakan sebagai landasan dalam penelitian ini adalah teori motivasi yang didasarkan atas pendekatan atau perspektif kognitif. Perspektif kognitif menyatakan bahwa siswa perlu diberikan kesempatan-kesempatan dan tanggung jawab untuk mengontrol prestasinya sendiri. Salah satu ahli yang termasuk pendukung pendekatan ini yaitu R.W. White yang dikutip oleh Winkel (1996:75) menyatakan bahwa, "manusia mempunyai motivasi internal untuk berinteraksi secara efektif dengan lingkungan”.

\section{Pengukuran Motivasi}

Pengukuran motivasi merupakan hal kritis dalam penelitian motivasi. Seperti dikemukakan dalam teori mengenai motivasi, terdapat sejumlah pendekatan terhadap motivasi. Dengan demikian terdapat sejumlah pengukuran motivasi, tergantung pada pendekatan yang digunakan.

Dalam observasi langsung, perilaku pemilihan tugas, upaya, kerajinan, kedisplinan dan ketekunan dapat dilihat sebagai indikator motivasi. Dalam laporan diri (self report), orang menilai diri sendiri melalui kuesioner, interview, stimulated recalls, think alouds dan dialog. Sedangkan dalam penelitian oleh orang lain, dilakukan penelitian terhadap perilaku individu yang diukur, dalam karakteristik-karakteristik yang menunjukkan motivasi.

Jadi yang dimaksud dengan motivasi belajar dalam penelitian ini adalah dorongan siswa dalam mencapai prestasi yang terbaik yang ditandai dengan beberapa indikator atau karakteristik yang menunjukkan motivasi, seperti perilaku, upaya, kerajinan, perhatian, kedisiplinan, ketekunan. 


\section{METODE}

Penelitian akan dilakukan di SMA Negeri 17 Kabupaten Tangerang yang berada di gugus 01 Kabupaten Tangerang, Komplek Perumahan Legok Indah, Kelurahan Babakan Kecamatan Legok Kabupaten Tangerang. Penelitian dilaksanakan selama 4 bulan terhitung dari bulan September 2016 sampai dengan Desember 2016.

Metode yang digunakan dalam penelitian ini adalah survey dengan teknik korelasional. Populasi dalam penelitian ini adalah Siswa kelas 10 SMA Negeri Gugus 01 Kabupaten Tangerang Tahun Pelajaran 2016/2017, yang dibatasi para sekolah siswa kelas 10 SMA Negeri 17 dan SMA Negeri 22 Kabupaten Tangerang dengan jumlah 560 siswa. Teknik pemilihan sampel dalam penelitian ini menggunakan teknik gabungan antara cluster dan random. Teknik cluster digunakan dalam mengelompokkan calon responden menurut kelas paralelnya, sedangkan teknik random digunakan dalam memilih anggota sampel dari setiap cluster yang ada. Jumlah anggota sampel dalam penelitian ini ditetapkan sebanyak 60 orang.

Sesuai dengan variabel penelitian, ada tiga jenis data yang dikumpulkan, yaitu tentang: 1) Intelegensi siswa, 2) Motivasi belajar siswa, dan 3) Prestasi belajar ekonomi siswa. Data intelegensi diperoleh dari dokumen sekolah yaitu hasil tes psikologi yang dilakukan oleh lembaga konsultasi psikologi pada saat siswa duduk di kelas 10. Data Motivasi belajar diperoleh dari hasil penyebaran quesioner dan Prestasi belajar siswa diambil dari hasil tes melalui soal yang diberikan kepada siswa sebanyak 60 0rang.

\section{HASIL DAN PEMBAHASAN}

1. terdapat pengaruh yang signifikan tingkat intelegensi dan motivasi belajar secara bersama-sama terhadap prestasi belajar Ekonomi. Hal ini dibuktikan dengan perolehan nilai Sig. 0,000<0,05 dan $F_{h}=13,037$. Sementara itu, persamaan garis regresi ganda dapat dinyatakan dengan $\hat{Y}=17,707+0,324 \mathrm{X}_{1}+0,295 \mathrm{X}_{2}$. Hal ini memiliki pengertian bahwa kenaikan satu skor variable tingkat intelegensi dan motivasi belajar memberikan kontribusi sebesar 0,324oleh $X_{1}$ dan 0,295 oleh $X_{2}$ terhadap variable prestasi belajar Ekonomi. menjelaskan bahwa secara bersama-sama variable tingkat intelegensi dan motivasi belajar memberikan kontribusi sebesar $31,4 \%$ terhadap variable prestasi belajar ekonomi. 
2. terdapat pengaruh yang signifikan tingkat intelegensi terhadap prestasi belajar Ekonomi. Hal ini dibuktikan dengan perolehan nilai Sig. 0,010<0,05 dan $t_{h}=2,674$. kontribusi tingkat intelegensi dalam meningkatkan prestasi belajar Ekonomi sebesar $15,81 \%$.

3. terdapat pengaruh yang signifikan motivasi belajar terhadap prestasi belajar Ekonomi. Hal ini dibuktikan dengan perolehan nilai Sig. 0,011<0,05 dan $t_{h}=2,644$. kontribusi motivasi belajar dalam meningkatkan prestasi belajar Ekonomi sebesar 15,55\%.

Hasil penelitian di atas menyimpulkan bahwa tingkat intelegensi dan motivasi belajar secara bersama-sama telah memberikan pengaruh positif terhadap peningkatan prestasi belajar Ekonomi Siswa SMA Negeri di Gugus 01 Kabupaten Tangerang. Hal ini mengandung arti bahwa tingkat intelegensi dan motivasi belajar telah memberikan pengaruh yang signifikan terhadap peningkatan prestasi belajar Ekonomi Siswa SMA Negeri di Gugus 01 Kabupaten Tangerang.

Terkait dengan belajar, banyak faktor yang mempengaruhi keberhasilan siswa dalam belajar. Secara garis besar faktor-faktor yang mempengaruhi belajar terbagi dua yakni faktor internal yaitu faktor yang terdapat dalam diri siswa dan eksternal, yaitu faktor yang berada diluar diri siswa. (Slameto, 2010 : 54) Faktor dalam diri (internal) menyangkut faktor jasmaniah seperti kesehatan jasmani, kesehatan panca indera, faktor rohaniah atau psikologis individu seperti kesehatan psikis, kemampuan intelektual, sosial, psikomotor serta kondisi afektif individu. Sedangkan faktor diluar diri siswa (eksternal) meliputi lingkungan sosial dan nonsosial, seperti lingkungan keluarga, lingkungan sekolah, keadaan udara atau cuaca sarana dan prasarana yang secara tidak langsung mempengaruhi siswa dalam belajar.

Winkel (1996: 128) mengemukakan: "terdapat lima kelompok faktor yang mempengaruhi prestasi belajar. Pertama, faktor yang ada pada pihak siswa, termasuk didalamnya inteligensi, motivasi belajar, perasaan-sikap-minat, keadaan sosio-ekonomis dan sosio-kultural, serta keadaan fisik dan psikis. Kedua, faktor pada pihak guru, termasuk dalam faktor ini adalah sifat dan sikap guru yang termanifestasi dalam perilakunya terhadap siswa, pemahaman dan keterampilan didaktis guru, dan corak interaksi antara guru-siswa dikelas. Faktor ketiga, adalah sekolah sebagai sistem sosial, atau sekolah sebagai susunan kedudukan orang dalam lingkungan kerja tertentu. Masingmasing kedudukan membawa peran tertentu yang akan mewarnai interaksi sosial antar 
orang-orang yang menempati kedudukan-kedudukan itu. Keempat, sekolah sebagai institut pendidikan formal, yaitu bahwa sekolah memiliki tujuan institusional yang berupaya dicapai melalui pengaturan yang dipimpin kepala sekolah. Kelima, faktorfaktor situasional seperti keadaan politik- ekonomi, waktu dan musim-iklim. Keadaan politik-ekonomi yang labil dapat menjadi kondisi yang kurang menguntungkan untuk belajar. Waktu belajar seperti jumlah jam belajar, juga keadaan musim-iklim, dapat mempengaruhi proses belajar. Berdasarkan uraian, dapat dilihat bahwa paling tidak, motivasi dan corak interaksi guru-siswa di kelas merupakan dua faktor yang dapat mempengaruhi prestasi belajar."

Hasil penelitian di atas menyimpulkan bahwa tingkat intelegensi telah memberikan pengaruh positif terhadap peningkatan prestasi belajar Ekonomi Siswa SMA Negeri di Gugus 01 Kabupaten Tangerang. Hal ini mengandung arti bahwa tingkat intelegensi memberikan pengaruh yang cukup signifikan terhadap prestasi belajar Ekonomi Siswa SMA Negeri di Gugus 01 Kabupaten Tangerang.

Inteligensi (IQ) tinggi akan dapat memperoleh prestasi belajar yang tinggi pula, karena Inteligensi (IQ) merupakan bekal potensial yang akan memudahkan dalam belajar dan pada gilirannya akan menghasilkan prestasi belajar yang optimal. Walaupun demikian, dalam proses belajar-mengajar di sekolah sering ditemukan siswa yang tidak dapat meraih prestasi belajar yang setara dengan kemampuan Inteligensinya. Ada siswa yang mempunyai kemampuan Inteligensi (IQ) tinggi tetapi memperoleh prestasi belajar yang relatif rendah, bahkan ada siswa yang walaupun kemampuan Inteligensinya relatif rendah dapat meraih prestasi belajar yang relatif tinggi.

Inteligensi atau kemampuan menerima dan memecahkan masalah adalah faktor yang menggerakkan siswa sehingga ia berhasil atau gagal dalam menghadapi lingkungan belajarnya. Dari hasil penelitian dan teori yang ada dapat disimpulkan bahwa motivasi belajar telah memberikan pengaruh positif terhadap peningkatan prestasi belajar Ekonomi Siswa SMA Negeri di Gugus 01 Kabupaten Tangerang. Artinya, motivasi belajar yang tinggi telah memberikan pengaruh yang signifikan terhadap peningkatan prestasi belajar Ekonomi Siswa SMA Negeri di Gugus 01 Kabupaten Tangerang.

Dengan demikian dapat dikatakan bahwa walaupun tak dapat dilihat secara langsung, motivasi dapat diukur dengan perilaku-perilaku tertentu. 
Dalam motivasi terkandung tujuan-tujuan yang merupakan pendorong dan pengarah tindakan. Pandangan kognitif terhadap motivasi menekankan pentingnya tujuan. Tujuan kemungkinan tidak dapat diformulasikan dengan baik, dan mungkin berubah bersama dengan diperolehnya pengalaman. Motivasi ada yang timbul sebagai hasil proses dari dalam diri (motivasi intrinsik), dan yang timbul karena pengaruh dari luar diri atau lingkungan (motivasi ekstrinsik). Motivasi belajar dapat ditinjau sebagai hal yang terkait dengan perkembangan manusia.

\section{SIMPULAN}

1. Terdapat pengaruh yang signifikan tingkat intelegensi dan motivasi belajar secara bersama-sama terhadap prestasi belajar Ekonomi Siswa SMA Negeri di Gugus 01 Kabupaten Tangerang. Hal ini dibuktikan dengan perolehan nilai Sig. 0,000 < 0,05 dan $F_{h}=13,037$. Secara bersama-sama tingkat intelegensi dan motivasi belajar memberikan kontribusi sebesar 31,4\% terhadap variable prestasi belajar Ekonomi.

2. Terdapat pengaruh yang signifikan tingkat intelegensi terhadap prestasi belajar Ekonomi Siswa SMA Negeri di Gugus 01 Kabupaten Tangerang. Hal ini dibuktikan dengan perolehan nilai Sig. $0,010<0,05$ dan $t_{h}=2,674$. Variabel tingkat intelegensi memberikan kontribusi sebesar $15,81 \%$ dalam meningkatkan prestasi belajar Ekonomi.

3. Terdapat pengaruh yang signifikan motivasi belajar terhadap prestasi belajar Ekonomi Siswa SMA Negeri di Gugus 01 Kabupaten Tangerang. Hal ini dibuktikan dengan perolehan nilai Sig. 0,011<0,05 dan $t_{h}=2,644$. Variabel motivasi belajar memberikan kontribusi sebesar 15,55\% dalam meningkatkan prestasi belajar Ekonomi.

\section{UCAPAN TERIMA KASIH}

Dengan ini penulis mengucapkan rasa syukur kepada Allah SWT yang telah memberikan rahmat dan hidayah-Nya, serta penulis mengucapkan terima kasih kepada seluruh Sekolah Menengah Atas Negeri di gugus 01 Kabupaten Tangerang, serta ucapan terima kasih kepada semua pihak yang telah membantu. 
Research and Development Journal of Education

Vol. 3 No.1 Oktober 2016

ISSN 2406-9744

\section{DAFTAR PUSTAKA}

Djaali, H, 2008. Psikologi Pendidikan, Jakarta : Bumi Aksara.

Hamalik, Oeman, 2006. Pendidikan Guru Berdasarkan Pendekatan Kompetensi . Jakarta : Bumi Aksara.

Mulyasa, E, 2004. Standar Kompetensi dan Sertifikasi Guru, Bandung : Remaja Rosda Karya.

Slameto, 2010. Belajar Dan Faktor-faktor Yang Mempengaruhinya, Jakarta : Rineka Cipta.

Winkel, W.S, 1996. Psikologi Pengajaran, Edisi Yang Disempurnakan, Cetakan ke-4, Jakarta : Erasindo 